\title{
Differentiated Products and Evasion of Import Tariffs
}

\author{
Beata S. Javorcik ${ }^{\star}$ \\ and \\ Gaia Narciso $^{* *}$
}

\begin{abstract}
An emerging literature has demonstrated some unique characteristics of trade in differentiated products. This paper contributes to the literature by postulating that differentiated products may be subject to greater tariff evasion due to the difficulties associated with assessing their quality and price. Using product-level data on trade between Germany and 10 Eastern European countries during 1992-2003, we find empirical support for this hypothesis. We show that the trade gap, defined as the discrepancy between the value of exports reported by Germany and the value of imports from Germany reported by the importing country, is positively related to the level of tariff in 8 out of 10 countries. Further, we show that the responsiveness of the trade gap to the tariff level is greater for differentiated products than for homogeneous goods. A one-percentage-point increase in the tariff rate is associated with a $0.6 \%$ increase in the trade gap in the case of homogeneous products and a $2.1 \%$ increase in the case of differentiated products. Finally, the data indicate that greater tariff evasion observed for differentiated products tends to take place through misrepresentation of the import prices.
\end{abstract}

Keywords: differentiated products, tariff evasion, transition countries

World Bank Policy Research Working Paper 4123, February 2007

The Policy Research Working Paper Series disseminates the findings of work in progress to encourage the exchange of ideas about development issues. An objective of the series is to get the findings out quickly, even if the presentations are less than fully polished. The papers carry the names of the authors and should be cited accordingly. The findings, interpretations, and conclusions expressed in this paper are entirely those of the authors. They do not necessarily represent the view of the World Bank, its Executive Directors, or the countries they represent. Policy Research Working Papers are available online at http://econ.worldbank.org.

\footnotetext{
* World Bank and CEPR, MSN MC3-303, 1818 H St, NW, Washington DC, 20433. Email:

bjavorcik@worldbank.org.

** Bocconi University, IEP, via Gobbi 5, 20136, Milano, Italy. Email: gaia.narciso@unibocconi.it.

The authors wish to thank Torfinn Harding, Leonardo Iacovone, Bernard Hoekman, Molly Lipscomb, Maurice Schiff, Antonio Spilimbergo and David Tarr for their helpful comments and suggestions and Geoff Revell for research assistance.
} 


\section{Introduction}

As many developing and transition countries rely on import tariffs as an important source of revenue, ${ }^{1}$ evasion of customs duties has attracted a lot of attention from policy makers. For instance, a report released by the state's budgetary watchdog, the Audit Chamber, found that the Russian customs service was plagued by corruption which was costing the state billions of dollars annually (Baumgartner, 2001). An investigation by the Supreme Board of Inspection (NIK) in Poland suggested that importers used various methods to artificially lower the value of imported goods, including fake invoices and double invoicing (Polish News Bulletin, 2000). Revenue loss aside, there are other undesirable effects of tariff evasion. It boosts the profitability of well-connected firms at the expense of honest producers and importers. It may hinder the accession process to the World Trade Organization and hurt the image of the country as an attractive location for foreign direct investment.

The purpose of this study is to enhance our understanding of tariff evasion-concealment of dutiable imports by private parties (individuals or private firms). It aims to do so in three ways. First, it documents the existence of tariff evasion in transition countries by demonstrating that in 8 out of 10 Eastern European economies, the discrepancy between the export figures reported by Germany and the import data recorded by the importing economy is systematically related to the tariff level. ${ }^{2}$ In this way, it shows the generality of the pattern found for China by Fisman and Wei (2004). It also improves on Fisman and Wei's work by relying on panel data rather than mostly cross-sectional information. Second, it finds that tariff evasion is more prevalent for differentiated products, as defined by Rauch (1999). This result is intuitive as it is more difficult to accurately assess the price of differentiated products, which means that honest customs officers find it more difficult to detect an invoice stating an incorrect price and corrupt customs officers have a plausible explanation for why they did not detect the problem with the invoice. ${ }^{3}$ Third, the study shows that tariff evasion in the case of differentiated product tends to take place by misrepresenting the price of imported goods rather than by undercounting physical quantities or misclassifying products.

\footnotetext{
${ }^{1}$ Customs and other import duties accounted for $62 \%$ of tax revenue in the Maldives, $55 \%$ in Lesotho, $50 \%$ in Madagascar, 42\% in Bangladesh, 16\% in Tajikistan and 10\% in Ukraine (2004 figures from the World Bank's World Development Indicators).

${ }^{2}$ Note that while some discrepancy in trade data may be due to lower quality of data recording in Eastern European countries, in the absence of evasion such discrepancy would not be systematically related to the tariff rate.

${ }^{3}$ An investigation into customs import control launched by the Polish Supreme Board of Inspection showed that the value of imported goods, as included in customs declarations, was often "ridiculously low," which went unnoticed by customs officers. Importers used various methods to artificially lower the value of imported goods, including fake invoices issued by both foreign suppliers and the importers or double invoicing. In most such cases, according to the NIK report, customs officers either did not want or were unable to question the evident misrepresentation of prices. The verification of customs value of imported goods during customs clearance procedures was in most cases carried out according to the sole discretion of the customs officers on duty (Polish News Bulletin, 2000).
} 
Eastern Europe is a suitable environment for this study for three reasons. First, the weakness of its institutions, including the customs service, makes it prone to tariff evasion. For instance, in a 1999 survey $51 \%$ of firms in Romania, $45 \%$ in Lithuania and $44 \%$ in Ukraine believed that there was a need to make "additional payments" when dealing with customs. ${ }^{4}$ Second, trade liberalization taking place during the period under study gives us a significant variation in tariff rates across time and across products. As illustrated in Table A1 in Appendix I, during the period under study the average tariff rate in Poland declined from $11.8 \%$ to $1.9 \%$. The corresponding figures for Hungary were $12.9 \%$ and $5.6 \%$, while for Russia the change was from $12.1 \%$ to $10.4 \%$. Third, as all but two of the countries in the sample were preparing for their accession to the European Union during the time under study, the changes in their tariff rates were determined by the pre-accession agreements (European Agreements) and thus are not subject to endogeneity problems.

Taking Fisman and Wei's work as our starting point, we analyze the sensitivity of tariff evasion to tariff rates and identify the type of products which are subject to greater evasion. We use data on ten Eastern European countries over the time period 1992-2003. We measure the trade gap as the difference between the value of exports from Germany to each country in the sample as reported by Germany and the value of imports from Germany as reported by each importing country. Considering the same trading partner for all importers in the sample ensures that the export data are measured consistently. We choose to focus on German exports, as Germany was a major trading partner of all countries in the sample accounting for $31 \%$ of total imports in the Czech Republic, a quarter of imports in both Hungary and Poland and 19\% in Slovenia. The lowest share of German imports was registered in Ukraine where they accounted for only $9 \%$ of the total (see Table A2 in Appendix I). The trade figures come from the United Nations' COMTRADE database and are available at the product level (6-digit category in the Harmonized System (HS) classification HS1988/92). Depending on the country, our data set includes information on between 1,433 and 2,785 products for years between 1992 and 2003. The tariff data, applied by each importing country to imports from Germany, measured also at the 6-digit HS level, have been obtained from the UNCTAD's TRAINS database.

We find a positive and significant relationship between the tariff level and the trade gap. This relationship holds for 8 out of 10 countries as well as for the pooled sample. It is robust to including 6digit product dummies and country-year fixed effects. The responsiveness of the trade gap to the tariff level is found to be the highest for Ukraine and the Russian Federation, both of which appear to have a

\footnotetext{
${ }^{4}$ The data come from the Business Environment and Enterprise Performance Survey (BEEPS), conducted jointly by the World Bank and the European Bank for Reconstruction and Development. The statistics pertain to the percentage of firms which answered "always," "mostly," "frequently," "sometimes" or "seldom" to the question "How frequently do firms in your line of business have to pay some irregular "additional payments" to deal with customs and imports?"
} 
high level of corruption in the customs service according to the BEEPS survey mentioned earlier. It is also interesting to note that no statistically significant relationship is found for Slovenia which is the country with the lowest incidence of customs corruption as reported in BEEPS.

In addition to testing the relationship between tariff levels and evasion, we ask what kind of products are more likely to be subject to evasion. We consider Rauch's (1999) definition of differentiated products and argue that for such products it may be easier to conceal their true value. We confirm our hypothesis by showing that the trade gap is more responsive to the tariff level in the case of differentiated goods than in the case of homogeneous products. This result holds for both a liberal and a conservative definition of differentiated products and is robust to several specifications. The magnitude of the effect is economically meaningful. A one-percentage-point increase in the tariff rate is associated with a $0.6 \%$ increase in trade gap in the case of homogeneous products and a $2.1 \%$ increase in the case of differentiated products.

Finally, we consider three channels through which tariff evasion may take place. These are: (i) misrepresenting the price of imported products; (ii) undercounting physical quantities of imported products, and (iii) misclassification of high tariff products as a lower tariff variety. We find strong evidence of price misrepresentation in the case of differentiated products. More specifically, our results indicate that the gap in the unit values of exports reported by Germany and imports reported by the destination country (which captures reporting a lower than actual price of imports) is positively correlated with the tariff level. This effect is positive and statistically significant in the case of differentiated products, but not for all other goods. We find little evidence of undercounting of physical quantities. Neither do we find evidence of product misclassification when we consider misclassification within the same 4-digit HS sector. We conclude that the difficulties associated with assessing the price of differentiated products make them particularly prone to tariff evasion.

Our study is related to the literature documenting evasion of import duties in developing countries. In their 1970 volume, Little, Scitovsky and Scott pointed out that evasion of import duties through smuggling was a major problem in Mexico, Argentina and the Philippines. Bhagwati (1964) discussed the prevalence of under-invoicing as a method of tariff evasion. The type of corruption that involved import duty evasion in which briber and bribee collude to rob the public was referred by Shleifer and Vishny (1993) as "corruption with theft." Pritchett and Sethi (1994) examined the data from three developing countries (Jamaica, Kenya and Pakistan) and found that collected and official tariff rates are only weakly related, the variance of the collected rate increases strongly with the level of the official rate and the collected rate increases much less than one-for-one with increases in the official rate. The relationship between evasion and tariff rates was analyzed by Fisman and Wei (2004) who found that import duty evasion rises with the tariff rate. Comparing the values of imports from Hong Kong as 
reported by China with the Hong Kong data on its exports to China at the product level for 1998 they demonstrated that a one-percentage-point increase in the tariff rate was on average associated with a three percent increase in underreporting. ${ }^{5}$

Our study also contributes to the emerging literature on differentiated products. In his seminal work, Rauch (1999) classified goods into three categories. He defined homogeneous goods as products whose price is set on organized exchanges. Goods which are not traded on organized exchanges, but possess a benchmark price, were defined as reference priced. Finally, products whose price is not set on organized exchanges and which lack a reference price because of their intrinsic features were labeled as differentiated. Rauch argued that search costs tend to be higher for differentiated products relative to homogeneous goods and showed that colonial ties and common language are more relevant for trade in differentiated products than trade in homogeneous goods. In subsequent work, Rauch and Trinidade (2002) found that the positive impact of ethnic Chinese networks on bilateral trade is greater for differentiated products relative to homogeneous ones. In line with this result, Rauch and Casella (2003) showed that the higher the degree of product differentiation the larger the impact of international ties between wholesalers on bilateral trade. Fink, Mattoo and Neaugu (2002) provided evidence that the effect of communication costs on trade is larger for differentiated products. Feenstra, Markusen and Rose (2001) showed that home market effects are more pronounced for differentiated than for homogeneous products, while Evans (2003) found that the higher the degree of product differentiation, the smaller the border effects. In a recent paper, Besedes and Prusa (2006) showed that transactions in differentiated goods tend to start involving smaller values than transactions of homogeneous goods and that trade relationships tend to be longer for differentiated products than for homogeneous ones.

While our study does not explicitly analyze the effects of customs reform, its results suggest that a system which gives customs officials discretion and does not involve effective audits or secondary inspections is likely to lead to tariff evasion. Corrupt behavior aside, the ability of the customs official to evaluate invoice prices may be greatly enhanced by computerization and international agreements that allow them to obtain verification from foreign institutions about the validity of documents presented by

\footnotetext{
${ }^{5}$ Our work is also related to a more general literature on tax evasion. While many theoretical models have analyzed the impact of tax rates on evasion, Slemrod and Yitzhaki (2000) concluded in their survey paper that theoretical findings are not clear-cut, as they strongly depend on modeling assumptions. Contrasting results are provided by empirical studies as well. Clotfelter (1983) and Feinstein (1991), who study the impact of tax rates on tax evasion by using the U.S. Taxpayers Compliance Measurement Program data, ended up drawing opposite conclusions. Cloetfleter found a positive relationship, while Feinstein, who employed a subset of the dataset, provided evidence of a negative relationship.
} 
importers. Our results also provide evidence in favor of having a uniform tariff structure which would dampen the incentives to misclassify imported products. ${ }^{6}$

This study is structured as follows. Section 2 describes the data. Section 3 explores the relationship between tariff rates and evasion. Section 4 presents the empirical results on tariff evasion for differentiated products, and Section 5 examines the channels through which such evasion takes place. Section 6 concludes.

\section{Data}

Our first data source is the World Bank's World Integrated Trade Solution (WITS) database. This database contains information on MFN and preferential tariff rates specific to pairs of countries and years, derived from the UNCTAD's Trade Analysis and Information System (TRAINS). The tariff information is available at the 6-digit Harmonized System level. We focus on 8 Eastern European countries acceding to the European Union (Bulgaria, Czech Republic, Hungary, Latvia, Lithuania, Poland, Romania and Slovenia) as well as on the Russian Federation and Ukraine. ${ }^{7}$ As most of these countries have preferential trade agreements with the European Union, we use information on applied tariffs.

As illustrated in Table 1, tariff rates differ substantially across the countries considered. Lithuania has the lowest average tariff rate of $3.64 \%$, as a large percentage of products are subject to zero tariff, while Russian Federation shows the highest average tariff rate of $12.58 \%$. Slovenia is the country with the lowest maximum tariff rate, around 49\%. A large fraction of imports is not taxed in Poland, although the variance in Polish tariffs is very high, due to the high tariff rates applied to tobacco imports (up to 295\%). It is relevant to note that all countries in the sample undertook trade liberalization during the time period under study and their tariff rates decreased significantly over time (see Table A1 in Appendix I).

Our second data source is the United Nations' COMTRADE database which includes information on trade flows, also at the 6-digit level. The data on tariffs and trade flows are available for the period 1992-2003, though the coverage differs by country (see Appendix I for more details). Using COMTRADE data we calculate the trade gap, which is defined as the log difference between the value of exports from Germany to each country in the sample as reported by Germany and the value of imports from Germany as reported by each partner country.

\footnotetext{
${ }^{6}$ The theoretical arguments in favor of a uniform tariff structure are usually based on political economy considerations and incentives for tariff evasion (see Panagariya and Rodrik 1993; Tarr 2002; Anderson and Neary 2006).

${ }^{7}$ Data constraints prevent us from including other post-Soviet transition countries in the sample. Unfortunately, WITS does not include ad valorem equivalents of specific tariffs which may be prevalent in the countries not acceding to the EU. However, not controlling for specific tariffs is likely to work against us finding a relationship between trade evasion and tariff level. As specific tariffs are more likely to be imposed on agricultural products, in our robustness checks we will exclude these products from the sample.
} 
As can be seen in the lower panel of Table 1, there are significant differences in the trade gap across countries. A discrepancy between the value of exports recorded by the exporting country and the value of imports recorded by the importer is to be expected. The first reason is that export prices are expressed in f.o.b. terms while imports are recorded including the cost of insurance and freight (c.i.f.). The second reason is that countries tend to monitor imports more carefully than exports. Thus, in the absence of tariff evasion one would expect the discrepancy to be negative. And indeed the reported value of imports exceeds that of exports in 6 out of 10 countries. The largest difference is observed in Latvia, Russia and Ukraine, which are located farther away from Germany than Poland, the Czech Republic or Hungary and thus their imports may need to incur higher transport costs. However, as illustrated in Table 1, in 4 out of 10 countries we observe a positive gap which means that on average Germany recorded higher exports of a particular product line than the imports recorded by a transition country. The extent of underreporting (i.e., the positive gap) ranges from $6 \%$ in the case of Hungary to $12 \%$ in Bulgaria, $14 \%$ in the Czech Republic and 16\% in Slovenia. ${ }^{8}$

Table 1: Tariff rates and trade gap by country.

\begin{tabular}{|c|c|c|c|c|c|}
\hline \multirow[b]{2}{*}{ Country } & \multicolumn{5}{|c|}{ Tariff rates } \\
\hline & Mean & $\begin{array}{l}\text { Standard } \\
\text { deviation }\end{array}$ & Minimum & Maximum & Obs. \\
\hline Bulgaria & 3.96 & 7.18 & 0 & 68 & 3,453 \\
\hline Czech Republic & 4.26 & 6.44 & 0 & 168 & 16,187 \\
\hline Hungary & 8.50 & 11.72 & 0 & 150 & 22,725 \\
\hline Latvia & 4.51 & 7.65 & 0 & 88 & 13,122 \\
\hline Lithuania & 3.64 & 7.45 & 0 & 70 & 10,284 \\
\hline Poland & 5.19 & 13.79 & 0 & 295 & 17,817 \\
\hline Romania & 7.23 & 9.20 & 0 & 144 & 9,874 \\
\hline Russian Federation & 12.58 & 7.80 & 0 & 100 & 16,575 \\
\hline Slovenia & 6.78 & 7.23 & 0 & 49.2 & 10,546 \\
\hline \multirow[t]{2}{*}{ Ukraine } & 8.85 & 8.98 & 0 & 70 & 11,825 \\
\hline & \multicolumn{5}{|c|}{ Trade gap } \\
\hline Country & Mean & $\begin{array}{l}\text { Standard } \\
\text { deviation }\end{array}$ & Minimum & Maximum & Obs. \\
\hline Bulgaria & 0.11 & 1.20 & -6.24 & 7.58 & 3,453 \\
\hline Czech Republic & 0.13 & 1.10 & -7.28 & 8.04 & 16,187 \\
\hline Hungary & 0.06 & 1.31 & -7.39 & 8.23 & 22,725 \\
\hline Latvia & -5.96 & 2.72 & -14.65 & 6.50 & 13,122 \\
\hline Lithuania & -0.08 & 1.23 & -7.14 & 8.47 & 10,284 \\
\hline Poland & -0.41 & 2.05 & -10.40 & 6.47 & 17,817 \\
\hline Romania & -0.01 & 1.30 & -7.40 & 7.52 & 9,874 \\
\hline
\end{tabular}

\footnotetext{
${ }^{8}$ Note that these percentages are calculated as the exponent of the values reported in Table 1.
} 


\begin{tabular}{lccccc} 
Russian Federation & -5.45 & 2.98 & -15.51 & 9.41 & 16,575 \\
Slovenia & 0.15 & 1.33 & -7.17 & 8.90 & 10,546 \\
Ukraine & -2.88 & 3.85 & -14.05 & 7.56 & 11,825 \\
\hline \multicolumn{4}{l}{ Notes: trade gap $=\ln \left(\right.$ exports reported by Germany) pt $_{\mathrm{pt}}-\ln$ (imports reported by the } \\
importing country) $)_{\mathrm{pt}}$ where p stands for a 6-digit HS product and t for year.
\end{tabular}

\section{Tariff rates and Trade gap}

It is reasonable to expect that the incentive of importers to evade import duties increases with the tariff rate. And indeed Fisman and Wei (2004) find a positive relationship between the trade gap and the tariff rate in China. But does this relationship hold in other countries or are Chinese importers unique in their ability to conceal imports? As many transition countries had significantly lower tariffs than the average rate of $17.6 \%$ imposed by China on imports from Hong Kong in 1998, the year considered by Fisman and Wei, does the relationship between evasion and tariff level hold in transition economies?

Table 2: Trade gap by tariff rate.

\begin{tabular}{|c|c|c|c|}
\hline \multirow{2}{*}{ Country } & \multicolumn{3}{|c|}{ Trade Gap } \\
\hline & $\begin{array}{c}\text { Tariff below median } \\
\text { (1) }\end{array}$ & $\begin{array}{c}\text { Tariff above median } \\
(2)\end{array}$ & $\begin{array}{l}\text { Difference } \\
(2)-(1)\end{array}$ \\
\hline \multirow{2}{*}{ Bulgaria } & 0.00 & 0.23 & 0.23 \\
\hline & (1751 products) & (1702 products) & \\
\hline \multirow{2}{*}{ Czech Republic } & 0.09 & 0.19 & 0.10 \\
\hline & (9874 products) & (6313 products) & \\
\hline \multirow{2}{*}{ Hungary } & -0.03 & 0.15 & 0.18 \\
\hline & (11663 products) & (11062 products) & \\
\hline \multirow{2}{*}{ Latvia } & -6.05 & -5.82 & 0.24 \\
\hline & (8126 products) & (4996 products) & \\
\hline \multirow{2}{*}{ Lithuania } & -0.12 & 0.03 & 0.15 \\
\hline & (7510 products) & (2774 products) & \\
\hline \multirow{2}{*}{ Poland } & -0.25 & -0.80 & -0.55 \\
\hline & (12888 products) & (4929 products) & \\
\hline \multirow{2}{*}{ Romania } & -0.08 & 0.09 & 0.17 \\
\hline & (6002 products) & (3872 products) & \\
\hline \multirow{2}{*}{ Russian Federation } & -5.60 & -5.24 & 0.36 \\
\hline & (9815 products) & (6760 products) & \\
\hline \multirow{2}{*}{ Slovenia } & 0.14 & 0.16 & 0.01 \\
\hline & (7829 products) & (2717 products) & \\
\hline \multirow{2}{*}{ Ukraine } & -3.16 & -2.48 & 0.68 \\
\hline & (6996 products) & (4829 products) & \\
\hline
\end{tabular}


Notes: trade gap $=\ln (\text { exports reported by Germany })_{\mathrm{pt}}-\ln ($ imports reported by the importing country $)_{\mathrm{pt}}$ where $\mathrm{p}$ stands for a 6 -digit HS product and t for year. The median tariff values are calculated for each country and each year.

To shed some light on these questions, we start by presenting simple summary statistics of the trade gap for each country in our sample. In each country, we split the products into those with the tariff above the median rate and those with the tariff below the median (Table 2). In all countries, except for Poland, the trade gap is higher for products whose tariffs are above the median. For instance, while in Bulgaria there is no trade gap for products with low protection, in the case of goods with above median tariff rate the discrepancy increases to $26 \%$. In Hungary, the value of exports of products with a below median tariff rate is $3 \%$ lower than the value of imports, but in the case of above median tariff rates, exports are underreported by $16 \%$. These summary statistics are consistent with the idea that the gap value is a proxy for tariff evasion. We obtain similar results when we split the sample between products with the top $25 \%$ tariff rates versus the rest. The puzzling result regarding Poland may be explained by the high percentage of products subject to zero tariffs. The percentage of products exempt from tariffs increased from 12\% in 1998 to $89 \%$ in 1999 and remained well above $90 \%$ in the following years.

Next we estimate a simple model of the trade gap as a function of the tariff rate and year fixed effects. We do so for each country $c$ in the sample separately.

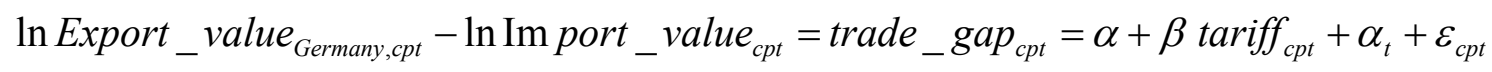

where $p$ stands for a 6-digit product and $t$ for year. Our prior is that if the gap value is a good proxy for tariff evasion then the estimated coefficient of the tariff rate should be positive and significant.

The results, reported in Table 3, are consistent with the summary statistics presented earlier. The estimated coefficient on the tariff rate is positive and significant at the $1 \%$ level for all the countries but Slovenia and Poland. The higher the tariff rate, the lower the value of imports reported by the importing country relative to the reported exports (i.e, the higher the trade gap). A one-percentage-point increase in the tariff level is associated with a $4.4 \%$ increase in the trade gap in Ukraine, $3.2 \%$ increase in the Russian Federation and $0.8 \%$ increase in Hungary. These results are in line with Fisman and Wei's study which finds a $3 \%$ increase. $^{9}$

It is interesting to note that Ukraine, the country with the highest estimated elasticity, has the second highest prevalence of corruption in customs as reported in the BEEPS survey. Slovenia, a country for which there is no statistically significant relationship, is ranked as the cleanest country in terms of corruption in customs according to BEEPS. See Appendix II for more details. The insignificant

\footnotetext{
${ }^{9}$ Note that these calculations do not take into account the direct effect an increase in a tariff rate may have on the volume of imports.
} 
coefficient found in the case of Poland is likely to be driven by the high percentage of products which are subject to zero tariff. 
Table 3: Trade gap and tariff rate by country.

\begin{tabular}{|c|c|c|c|c|c|c|c|c|c|c|}
\hline & (1) & $(2)$ & (3) & (4) & (5) & (6) & (7) & (8) & (9) & (10) \\
\hline & Bulgaria & $\begin{array}{l}\text { Czech } \\
\text { Republic }\end{array}$ & Hungary & Latvia & Lithuania & Poland & Romania & Russia & Slovenia & Ukraine \\
\hline & \multicolumn{10}{|c|}{ Trade Gap } \\
\hline Tariff & $\begin{array}{l}0.009 \\
(0.003)^{* * *}\end{array}$ & $\begin{array}{l}0.015 \\
(0.003)^{* * *}\end{array}$ & $\begin{array}{l}0.008 \\
(0.001)^{* * *}\end{array}$ & $\begin{array}{l}0.022 \\
(0.004)^{* * *}\end{array}$ & $\begin{array}{l}0.013 \\
(0.003)^{* * *}\end{array}$ & $\begin{array}{l}0.000 \\
(0.001)\end{array}$ & $\begin{array}{l}0.01 \\
(0.003)^{* * *}\end{array}$ & $\begin{array}{l}0.032 \\
(0.004)^{* * *}\end{array}$ & $\begin{array}{l}-0.004 \\
(0.004)\end{array}$ & $\begin{array}{l}0.044 \\
(0.005)^{* * *}\end{array}$ \\
\hline Observations & 3453 & 16187 & 22725 & 13122 & 10284 & 17817 & 9874 & 16575 & 10546 & 11825 \\
\hline Adj. R-squared & 0.004 & 0.009 & 0.007 & 0.005 & 0.010 & 0.674 & 0.005 & 0.011 & 0.0001 & 0.011 \\
\hline
\end{tabular}

All models include year fixed effect and a constant. Standard errors, clustered on 6-digit products, are listed in parentheses.

$*$ significant at $10 \% ; * *$ significant at $5 \% ; * * *$ significant at $1 \%$.

\section{Trade gap, tariff rates and differentiated products}

As mentioned earlier, differentiated products may lend themselves more readily to tariff evasion than homogeneous goods as their price depends on many attributes some of which may not be easily verifiable by a person unfamiliar with the product. Therefore, in the case of differentiated products it is more difficult for honest customs officers to detect an invoice stating an incorrect price and corrupt customs officers have a plausible explanation for why they failed to detect the problem with the invoice.

In our analysis, we use the classification of differentiated products developed by Rauch (1999). Rauch defined differentiated products as those not having a reference price or those whose price is not quoted on organized exchanges. Wheat and diamonds are classified as homogeneous goods, while coats and jackets are considered to be differentiated products. Rauch suggested two definitions, a conservative and a liberal one, in order to account for the ambiguities arising in the classification. The conservative definition minimizes the number of commodities that are classified as homogeneous goods, while the liberal definition maximizes this number. We employ both classifications, although the results do not differ substantially between the two. Rauch's definitions are based on the 4-digit SITC Rev. 2 classification, and we use the concordance provided by WITS to make it compatible with the 6-digit HS 1988/92 classification used in our data set.

Table 4, which reports the average trade gap for differentiated and homogeneous goods, confirms our prior about differentiated products lending themselves more readily to tariff evasion. For all countries but Latvia and the Czech Republic, the trade gap is larger for differentiated products than for homogeneous goods. For instance in Bulgaria, there is hardly any discrepancy for homogeneous products $(-2.6 \%$ in the case of the conservative and $-1.6 \%$ in the case of the liberal definition), but a significant trade gap is found for differentiated products $(16.6 \%$ and $17.6 \%$ for the conservative and liberal definition, respectively). In the case of Hungary, the gap increases from $3 \%$ for homogeneous goods to 
$6.7 \%$ for differentiated products when the conservative definition is used. The corresponding figures for the liberal definition are 2.2 and $7.4 \%$.

Table 4: Average tariff rates and trade gap by type of product.

\begin{tabular}{|c|c|c|c|c|}
\hline & \multicolumn{4}{|c|}{ Tariff rate } \\
\hline & Homogeneous & Differentiated & Homogeneous & Differentiated \\
\hline & \multicolumn{2}{|c|}{ Conservative } & \multicolumn{2}{|c|}{ Liberal } \\
\hline Bulgaria & 6.352 & 3.277 & 5.592 & 3.359 \\
\hline Czech Republic & 4.953 & 3.965 & 4.726 & 4.012 \\
\hline Hungary & 10.753 & 7.725 & 10.254 & 7.736 \\
\hline Latvia & 5.256 & 4.331 & 4.938 & 4.375 \\
\hline Lithuania & 4.381 & 3.447 & 3.603 & 3.651 \\
\hline Poland & 8.671 & 4.132 & 7.811 & 4.132 \\
\hline Romania & 9.858 & 6.372 & 8.937 & 6.513 \\
\hline Russian Federation & 9.222 & 13.717 & 10.120 & 13.655 \\
\hline Slovenia & 5.674 & 7.168 & 5.575 & 7.320 \\
\hline \multirow[t]{4}{*}{ Ukraine } & 7.878 & 9.096 & 7.763 & 9.211 \\
\hline & \multicolumn{4}{|c|}{ Trade Gap } \\
\hline & Homogeneous & Differentiated & Homogeneous & Differentiated \\
\hline & \multicolumn{2}{|c|}{ Conservative } & \multicolumn{2}{|c|}{ Liberal } \\
\hline Bulgaria & -0.026 & 0.154 & -0.016 & 0.162 \\
\hline Czech Republic & 0.141 & 0.125 & 0.115 & 0.138 \\
\hline Hungary & 0.030 & 0.065 & 0.022 & 0.071 \\
\hline Latvia & -5.906 & -5.978 & -5.937 & -5.973 \\
\hline Lithuania & -0.222 & -0.043 & -0.210 & -0.036 \\
\hline Poland & -0.466 & -0.388 & -0.473 & -0.379 \\
\hline Romania & -0.060 & 0.005 & -0.076 & 0.016 \\
\hline Russian Federation & -5.712 & -5.366 & -5.717 & -5.338 \\
\hline Slovenia & 0.114 & 0.157 & 0.108 & 0.163 \\
\hline Ukraine & -2.949 & -2.869 & -2.951 & -2.863 \\
\hline
\end{tabular}

Note that the upper panel in Table 4 indicates that for 7 out of 10 countries in the sample, the tariff rate on differentiated products is lower than the tariff rate on homogeneous goods. This allows us to have some confidence that the reported differences in trade gap between differentiated and homogeneous products are likely to be driven by evasion rather than differences in tariff rates.

To test whether differentiated products are more likely to be subject to underreporting, we pool all countries in the sample and regress the trade gap on the tariff rate, the differentiated product dummy 
and the interaction between the tariff rate and the differentiated product dummy. Our specification is as follows:

$$
\begin{aligned}
& \text { trade_gap }_{c p t}=\beta_{0}+\beta_{1} \text { tariff }_{c p t}+\beta_{2} \text { differentiated }_{-} \text {product }_{p}+ \\
& +\beta_{3} \text { tariff }_{c p t} * \text { differentiated }_{\text {product }}+\alpha_{c t}+\varepsilon_{c p t}
\end{aligned}
$$

where trade_gap ${ }_{c p t}$ is the gap value for the country $c$ importing product $p$ at time $t$; $\operatorname{tariff} f_{\text {cpt }}$ is the tariff rate imposed by country $c$ on imports of product $p$ from Germany at time $t$, differentiated_ product $_{p}$ is the differentiated product dummy based on Rauch's conservative or liberal definition, depending on the specification. To control for importing country-specific changes that may occur in a particular time period, such as a reform of the customs service or a decline in the incidence of corruption, we include country-year fixed effects. Thus to the extent that the introduction of computerization or an increase of salaries in the customs service affects tariff evasion across the board, it will be captured by these fixed effects. Finally, we cluster standard errors at the 6-digit product level.

In line with the evidence shown in the previous section, we expect the estimated coefficient for the tariff rate to be positive and significant. The higher the tariff rate, the higher the incentive for tax evasion, and the higher the expected gap. We are, however, primarily interested in the interaction between the tariff rate and the differentiated product dummy. Our prior is that the effect of the tax rate is higher for differentiated products relative to homogeneous ones. This is because differentiated product may make it easier for importers or corrupt customs officials to misrepresent the price of the imports. Classifying homogeneous goods is relatively straightforward and there is little variation in prices, thus misrepresenting the price could easily be detected. With differentiated products the wide range of potential uses, product characteristics and quality levels make the assessment of price more difficult, thus creating more room for tax evasion. Therefore, we expect the estimated coefficient $\beta_{3}$ to be positive.

The results, reported in Table 5, support our hypothesis that the positive relationship between the tariff rate and trade evasion is stronger for differentiated products. In the first column of Table 5, we confirm that the positive correlation between tariff levels and the trade gap holds in the pooled sample. In the second column, we employ the conservative definition of differentiated products and find that the estimated coefficient on the interaction term is positive and significant at the $1 \%$ level. This finding confirms our prior that the response of tariff evasion to the tariff rate is higher for differentiated products. Note that the differentiated product dummy itself is not significant suggesting that differentiated products differ in terms of the trade gap response to the tariff level but not in terms of the trade gap in general. As in the country regressions, the tariff coefficient remains positive and statistically significant, indicating that an increase in the tariff rate leads to an increase in the gap value, and hence to an increase in the evasion and underreporting of imports. The results hold when we consider the liberal definition of 
differentiated products (see column 3). Again, the responsiveness of evasion to an increase in the tariff rate is greater for differentiated products. The estimated coefficient of the interaction term is positive and statistically significant at the $1 \%$ level. The magnitude of the effect is economically meaningful. A onepercentage-point increase in the tariff rate is associated with a $0.6 \%$ increase in evasion in the case of homogeneous products and a $2.1 \%$ increase in the case of differentiated products ${ }^{10}$.

A potential concern is that our results may be driven by agricultural products which are homogeneous in nature and may be subject to non-tariff barriers. To check this possibility, in columns 4-6 we replicate the previous specifications excluding agricultural products (HS codes 010111 to 530599). The same results hold: the estimated coefficient of the tariff rate is still positive and statistically significant. Similarly, the interaction term between the tariff rate and the differentiated product dummy, both in the liberal and conservative definition, has a positive and highly significant impact on the trade gap.

\footnotetext{
${ }^{10}$ These magnitudes refer to the specification in column 2.
} 
Table 5: Trade, tariff rates and differentiated products.

\begin{tabular}{|c|c|c|c|c|c|c|}
\hline & $(1)$ & (2) & (3) & (4) & (5) & (6) \\
\hline & \multicolumn{6}{|c|}{ Trade Gap } \\
\hline Tariff & $\begin{array}{l}0.012 \\
(0.001)^{* * *}\end{array}$ & $\begin{array}{l}0.006 \\
(0.001)^{* * *}\end{array}$ & $\begin{array}{l}0.007 \\
(0.001)^{* * *}\end{array}$ & $\begin{array}{l}0.012 \\
(0.001)^{* * *}\end{array}$ & $\begin{array}{l}0.005 \\
(0.001)^{* * *}\end{array}$ & $\begin{array}{l}0.006 \\
(0.001)^{* * *}\end{array}$ \\
\hline $\begin{array}{l}\text { Tariff*Conservative } \\
\text { dummy }\end{array}$ & & $\begin{array}{l}0.015 \\
(0.002)^{* * *}\end{array}$ & & & $\begin{array}{l}0.016 \\
(0.002)^{* * *}\end{array}$ & \\
\hline Tariff*Liberal dummy & & & $\begin{array}{l}0.014 \\
(0.002)^{* * *}\end{array}$ & & & $\begin{array}{l}0.015 \\
(0.002)^{* * *}\end{array}$ \\
\hline Conservative dummy & & $\begin{array}{l}-0.009 \\
(0.03)\end{array}$ & & & $\begin{array}{l}0.009 \\
(0.032)\end{array}$ & \\
\hline Liberal dummy & & & $\begin{array}{l}0.015 \\
(0.029)\end{array}$ & & & $\begin{array}{l}0.032 \\
(0.03)\end{array}$ \\
\hline Agricultural products & Included & Included & Included & Excluded & Excluded & Excluded \\
\hline Observations & 132408 & 132408 & 132408 & 127893 & 127893 & 127893 \\
\hline Adjusted R-squared & 0.59 & 0.59 & 0.59 & 0.59 & 0.59 & 0.59 \\
\hline
\end{tabular}

As a robustness check, we introduce country-year fixed effects together with 6-digit product fixed effects thus controlling for country-specific changes in the performance of the customs service as well as unobservable product characteristics (see Table 6). The estimated coefficient of the interaction term is still positive and statistically significant at the $1 \%$ level in all specifications, both with and without agricultural products and both for the liberal and the conservative definition of differentiated products. The estimated elasticity of the trade gap with respect to the tariff rate is positive and significant in 4 out of 6 specifications. 
Table 6: Trade gap, tariff rates and differentiated products. Controlling for country-year fixed effects and 6-digit product fixed effects.

\begin{tabular}{|c|c|c|c|c|c|c|}
\hline & (1) & $(2)$ & (3) & (4) & $(5)$ & (6) \\
\hline & \multicolumn{6}{|c|}{ Trade Gap } \\
\hline Tariff & $\begin{array}{l}0.008 \\
(0.001)^{* * *}\end{array}$ & $\begin{array}{l}0.002 \\
(0.001)^{* *}\end{array}$ & $\begin{array}{l}0.003 \\
(0.001)^{* * *}\end{array}$ & $\begin{array}{l}0.007 \\
(0.001)^{* * *}\end{array}$ & $\begin{array}{l}0.001 \\
(0.001)\end{array}$ & $\begin{array}{l}0.002 \\
(0.001)\end{array}$ \\
\hline Tariff*Conservative & & 0.013 & & & 0.014 & \\
\hline Dummy & & $(0.002)^{* * *}$ & & & $(0.002)^{* * *}$ & \\
\hline Tariff*Liberal & & & 0.012 & & & 0.013 \\
\hline Dummy & & & $(0.002)^{* * *}$ & & & $(0.002)^{* * *}$ \\
\hline Agricultural products & Included & Included & Included & Excluded & Excluded & Excluded \\
\hline Observations & 132408 & 132408 & 132408 & 127893 & 127893 & 127893 \\
\hline Adjusted R-squared & 0.6 & 0.6 & 0.6 & 0.6 & 0.6 & 0.6 \\
\hline
\end{tabular}

As another robustness check, we estimate a model in first differences. This will allow us to eliminate the time-invariant effects specific to a particular product imported by a particular country. To control for importing country-specific time trends, e.g., an improvement in the quality of the customs services over time, we include importing-country fixed effects. Our estimating equation takes the following form:

$$
\Delta \text { trade_gap }{ }_{c p t}=\gamma_{0}+\gamma_{1} \Delta \text { tariff }_{c p t}+\gamma_{2} \Delta \text { tariff }_{c p t} * \text { differentiated_dummy }{ }_{p}+\lambda_{c}+\varepsilon_{c p t}
$$

Again, the estimation results confirm our earlier findings (see Table 7). The interaction term is positive and statistically significant for both the liberal and the conservative definition of differentiated products. The coefficient on tariff level, however, loses its significance. 
Table 7: Trade gap, tariff rates and differentiated products. Specification in first differences.

\begin{tabular}{|c|c|c|c|c|c|c|}
\hline & (1) & (2) & (3) & (4) & (5) & (6) \\
\hline & \multicolumn{6}{|c|}{$\Delta$ Trade Gap } \\
\hline$\Delta$ Tariff & $\begin{array}{l}0.001 \\
(0.002)\end{array}$ & $\begin{array}{l}-0.005 \\
(0.005)\end{array}$ & $\begin{array}{l}-0.004 \\
(0.004)\end{array}$ & $\begin{array}{l}0.002 \\
(0.002)\end{array}$ & $\begin{array}{l}-0.004 \\
(0.005)\end{array}$ & $\begin{array}{l}-0.002 \\
(0.004)\end{array}$ \\
\hline$\Delta$ Tariff*Conservative dummy & & $\begin{array}{l}0.012 \\
(0.005)^{* *}\end{array}$ & & & $\begin{array}{l}0.010 \\
(0.005)^{*}\end{array}$ & \\
\hline$\Delta$ Tariff*Liberal dummy & & & $\begin{array}{l}0.010 \\
(0.005)^{* *}\end{array}$ & & & $\begin{array}{l}0.008 \\
(0.005)^{*}\end{array}$ \\
\hline Agriculture & Included & Included & Included & Excluded & Excluded & Excluded \\
\hline Observations & 102989 & 102989 & 102989 & 99883 & 99883 & 99883 \\
\hline Adjusted R-squared & 0.0003 & 0.0003 & 0.0003 & 0.0003 & 0.0003 & 0.0003 \\
\hline
\end{tabular}

\section{Channels of tariff evasion}

In the light of the above findings, it is natural to ask how tariff evasion takes place. There are three potential channels through which importers may attempt to avoid or minimize the tariff payment: (i) misrepresenting the price of imported products; (ii) undercounting physical quantities of imported products, and (iii) misclassification of high tariff products as a lower tariff variety. In this section, we explore each of these evasion methods.

\subsection{Misrepresenting the price of imported products}

To examine the prevalence of misrepresenting the price of imports, we calculate the difference between the unit value of exports reported by Germany and the unit value of imports recorded by the importing country:

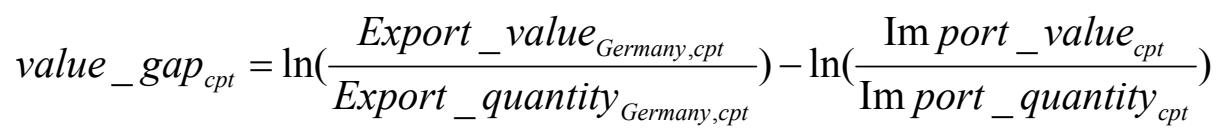

As before, the gap is calculated at the level of 6-digit HS product for each importing country and each year. 
Table 8: Unit value gap. Homogeneous versus differentiated products.

\begin{tabular}{|c|c|c|c|c|c|c|}
\hline & Mean & St. Dev & Homogene & fferentiated & Homogene & fferentiated \\
\hline Bulgaria & 0.29 & 1.06 & -0.146 & 0.417 & -0.120 & 0.445 \\
\hline Czech Republic & 0.21 & 0.80 & 0.021 & 0.288 & 0.036 & 0.301 \\
\hline Hungary & 0.18 & 0.84 & 0.006 & 0.246 & 0.013 & 0.260 \\
\hline Latvia & -5.83 & 2.44 & -5.920 & -5.803 & -5.920 & -5.795 \\
\hline Lithuania & 0.23 & 0.91 & -0.027 & 0.312 & 0.004 & 0.323 \\
\hline Poland & -0.37 & 1.97 & -0.495 & -0.329 & -0.457 & -0.332 \\
\hline Romania & 0.33 & 1.05 & 0.018 & 0.448 & 0.034 & 0.472 \\
\hline Russian Federation & -5.25 & 2.72 & -5.524 & -5.160 & -5.524 & -5.133 \\
\hline Slovenia & 0.14 & 0.86 & -0.146 & 0.235 & -0.129 & 0.256 \\
\hline Ukraine & -2.78 & 3.64 & -2.995 & -2.730 & -2.992 & -2.714 \\
\hline
\end{tabular}

Table 9: Unit value gap by tariff rate.

\begin{tabular}{|c|c|c|c|}
\hline \multirow[t]{2}{*}{ Country } & \multicolumn{3}{|c|}{ Unit Value Gap } \\
\hline & $\begin{array}{l}\text { Tariff below median } \\
\text { (1) }\end{array}$ & $\begin{array}{c}\text { Tariff above median } \\
\text { (2) }\end{array}$ & $\begin{array}{l}\text { Difference } \\
(2)-(1)\end{array}$ \\
\hline \multirow{2}{*}{ Bulgaria } & 0.15 & 0.43 & 0.27 \\
\hline & (1713 products) & (1700 products) & \\
\hline \multirow{2}{*}{ Czech Republic } & 0.18 & 0.25 & 0.07 \\
\hline & (9283 products) & (6065 products) & \\
\hline \multirow{2}{*}{ Hungary } & 0.14 & 0.23 & 0.09 \\
\hline & (11129 products) & (10720 products) & \\
\hline \multirow{2}{*}{ Latvia } & -5.90 & -5.70 & 0.20 \\
\hline & (7940 products) & (4918 products) & \\
\hline \multirow{2}{*}{ Lithuania } & 0.19 & 0.35 & 0.15 \\
\hline & (6639 products) & (2438 products) & \\
\hline \multirow{2}{*}{ Poland } & -0.20 & -0.80 & -0.60 \\
\hline & (12636 products) & (4873 products) & \\
\hline \multirow{2}{*}{ Romania } & 0.25 & 0.46 & 0.20 \\
\hline & (5114 products) & (3312 products) & \\
\hline \multirow{2}{*}{ Russian Federation } & -5.29 & -5.20 & 0.10 \\
\hline & (9625 products) & (6495 products) & \\
\hline \multirow{2}{*}{ Slovenia } & 0.08 & 0.30 & 0.22 \\
\hline & (7642 products) & (2655 products) & \\
\hline \multirow{2}{*}{ Ukraine } & -3.01 & -2.45 & 0.56 \\
\hline & (6820 products) & (4711 products) & \\
\hline
\end{tabular}


In the absence of evasion, we would expect the unit value gap to be negative, as import statistics include the cost of freight and insurance, neither of which is captured by the export data. However, as indicated in Table 8, in 6 out of 10 countries the average unit value gap is positive. It is even more striking that in all countries, the average unit value gap is larger for differentiated products. This is true for both the conservative and the liberal definition of differentiated products. Further, Table 9 suggests that in all but one country (Poland) the unit value gap is larger for products with the above median tariff rate.

To test this relationship more formally, we regress the unit value gap on the tariff rate, differentiated product dummy and the interaction between the two variables. To save space, we present only the specification estimated with country-year and product fixed effects and the specification in first differences. We restrict our attention to the sample excluding agricultural products. ${ }^{11}$

Table 10: Unit value gap.

\begin{tabular}{|c|c|c|c|c|c|c|}
\hline & (1) & (2) & (3) & (4) & (5) & (6) \\
\hline \multirow{3}{*}{ Tariff } & \multicolumn{3}{|c|}{ Levels } & \multicolumn{3}{|c|}{ First differences } \\
\hline & 0.000 & -0.001 & -0.001 & 0.003 & -0.004 & -0.003 \\
\hline & $(0.001)$ & $(0.001)$ & $(0.001)^{*}$ & $(0.002)$ & $(0.005)$ & $(0.004)$ \\
\hline Tariff*Conservative dummy & & 0.002 & & & 0.012 & \\
\hline & & $(0.001)^{*}$ & & & $(0.005)^{* *}$ & \\
\hline \multirow[t]{2}{*}{ Tariff*liberal dummy } & & & 0.003 & & & 0.010 \\
\hline & & & $(0.001)^{* *}$ & & & $(0.005)^{* *}$ \\
\hline Country-year fixed effects & Yes & Yes & Yes & No & No & No \\
\hline Product fixed effects & Yes & Yes & Yes & No & No & No \\
\hline Country fixed effects & No & No & No & Yes & Yes & Yes \\
\hline Agricultural products & Excluded & Excluded & Excluded & Excluded & Excluded & Excluded \\
\hline Observations & 121963 & 121963 & 121963 & 94658 & 94658 & 94658 \\
\hline Adjusted R-squared & 0.66 & 0.66 & 0.66 & 0.0001 & 0.0002 & 0.0002 \\
\hline
\end{tabular}

As evident in Table 10, we find no evidence of price misrepresentation (i.e., reporting unit values of imports as being lower than what they really are) being responsive to the tariff rate in general. On the contrary, in one case we find a negative and statistically significant coefficient on the tariff rate. However, we do find evidence suggesting that price misrepresentation is positively correlated with the tariff rate in the case of differentiated products. The results suggest that a one-percentage-point increase in the tariff

\footnotetext{
${ }^{11}$ Including agricultural products in the sample would not change the conclusions of this study.
} 
rate is associated with a $0.2 \%$ increase in the unit value gap. When we estimate a model in first differences, we confirm these findings and find an even larger effect: a one-percentage-point increase in the tariff rate is associated with a $1.2 \%$ increase in the value gap. The estimated coefficient is significant at the $5 \%$ level.

\subsection{Undercounting quantities of imported products}

Next we turn to another potential channel of tariff evasion, namely undercounting the quantities of imports, and we calculate the difference between the quantity of exports reported by Germany and the quantity of imports recorded by the importing country.

The summary statistics presented in Table 11 suggests that this channel of tariff evasion is much less prevalent. In 9 out of 10 countries, the quantity gap is negative suggesting that the quantities recorded by the importing country are larger than those recorded by Germany. The negative value is consistent with the stylized fact that countries tend to monitor their imports more carefully than exports.

Table 11: Quantity gap. Homogeneous versus differentiated products.

\begin{tabular}{|c|c|c|c|c|c|c|}
\hline & Mean & St. Dev & \multicolumn{2}{|c|}{$\begin{array}{c}\text { Homogeneous Differentiated } \\
\text { Conservative } \\
\end{array}$} & \multicolumn{2}{|c|}{$\begin{array}{c}\text { Homogeneous Differentiated } \\
\text { Liberal }\end{array}$} \\
\hline Bulgaria & -0.18 & 1.53 & 0.119 & -0.273 & 0.104 & -0.294 \\
\hline Czech Republic & -0.07 & 1.34 & 0.125 & -0.159 & 0.082 & -0.157 \\
\hline Hungary & -0.13 & 1.52 & 0.024 & -0.188 & 0.007 & -0.195 \\
\hline Latvia & -0.14 & 1.55 & 0.000 & -0.178 & -0.027 & -0.181 \\
\hline Lithuania & -0.33 & 1.49 & -0.202 & -0.370 & -0.219 & -0.375 \\
\hline Poland & -0.04 & 0.98 & 0.032 & -0.056 & -0.014 & -0.044 \\
\hline Romania & -0.38 & 1.63 & -0.076 & -0.488 & -0.112 & -0.502 \\
\hline Russian Federation & -0.21 & 1.70 & -0.184 & -0.216 & -0.190 & -0.216 \\
\hline Slovenia & 0.01 & 1.59 & 0.263 & -0.078 & 0.239 & -0.093 \\
\hline Ukraine & -0.12 & 1.73 & 0.052 & -0.162 & 0.045 & -0.174 \\
\hline
\end{tabular}


Table 12: Quantity gap by tariff rate.

\begin{tabular}{|c|c|c|c|}
\hline \multirow[t]{2}{*}{ Country } & \multicolumn{3}{|c|}{ Quantity Gap } \\
\hline & $\begin{array}{c}\text { Tariff below median } \\
\text { (1) }\end{array}$ & $\begin{array}{l}\text { Tariff above median } \\
\text { (2) }\end{array}$ & $\begin{array}{l}\text { Difference } \\
(2)-(1)\end{array}$ \\
\hline \multirow{2}{*}{ Bulgaria } & -0.17 & -0.20 & -0.02 \\
\hline & (1713 products) & (1700 products) & \\
\hline \multirow{2}{*}{$\begin{array}{l}\text { Czech } \\
\text { Republic }\end{array}$} & -0.08 & -0.06 & 0.02 \\
\hline & (9283 products) & (6065 products) & \\
\hline \multirow{2}{*}{ Hungary } & -0.18 & -0.08 & 0.10 \\
\hline & (11129 products) & (10720 products) & \\
\hline \multirow{2}{*}{ Latvia } & -0.16 & -0.12 & 0.04 \\
\hline & (7940 products) & (4918 products) & \\
\hline \multirow{2}{*}{ Lithuania } & -0.33 & -0.34 & -0.01 \\
\hline & (6639 products) & (2438 products) & \\
\hline \multirow{2}{*}{ Poland } & -0.05 & 0.00 & 0.05 \\
\hline & (12636 products) & (4873 products) & \\
\hline \multirow{2}{*}{ Romania } & -0.37 & -0.40 & -0.03 \\
\hline & (5114 products) & (3312 products) & \\
\hline \multirow{2}{*}{$\begin{array}{l}\text { Russian } \\
\text { Federation }\end{array}$} & -0.31 & -0.06 & 0.24 \\
\hline & (9625 products) & (6495 products) & \\
\hline \multirow{2}{*}{ Slovenia } & 0.07 & -0.15 & -0.22 \\
\hline & (7642 products) & (2655 products) & \\
\hline \multirow{2}{*}{ Ukraine } & -0.18 & -0.03 & 0.15 \\
\hline & (6820 products) & (4711 products) & \\
\hline
\end{tabular}

While the quantity gap is always negative for differentiated products, it is positive in the majority of countries when homogeneous products are considered. This is true in 7 out of 10 countries in the case of the conservative definition and in 5 out of 10 countries in the case of the liberal definition. It is may be easier to undercount quantities of homogeneous goods as they tend to be sold by weight rather than by piece. As expected, the quantity gap is larger for products with the above median tariff. This is true in 6 out of 10 countries considered (see Table 12).

When we repeat our econometric exercise with the quantity gap as the dependent variable, we find little support for undercounting being a major channel of tariff evasion. While the model in levels produces positive coefficients on the tariff rate as well as on its interaction with the differentiated product dummy, both coefficients lose their significance in a first difference specification (Table 13).

Table 13: Quantity gap. Homogeneous versus differentiated products. 


\begin{tabular}{|c|c|c|c|c|c|c|}
\hline & (1) & (2) & (3) & (4) & (5) & (6) \\
\hline & \multicolumn{3}{|c|}{ Levels } & \multicolumn{3}{|c|}{ First differences } \\
\hline Tariff & $\begin{array}{l}0.007 \\
(0.001)^{* * *}\end{array}$ & $\begin{array}{l}0.002 \\
(0.001)^{*}\end{array}$ & $\begin{array}{l}0.003 \\
(0.001)^{* * *}\end{array}$ & $\begin{array}{l}0.000 \\
(0.001)\end{array}$ & $\begin{array}{l}0.001 \\
(0.001)\end{array}$ & $\begin{array}{l}0.001 \\
(0.001)\end{array}$ \\
\hline Tariff*Conservative dummy & & $\begin{array}{l}0.012 \\
(0.001)^{* * *}\end{array}$ & & & $\begin{array}{l}-0.001 \\
(0.002)\end{array}$ & \\
\hline Tariff*liberal dummy & & & $\begin{array}{l}0.01 \\
(0.001)^{* * *}\end{array}$ & & & $\begin{array}{l}-0.001 \\
(0.002)\end{array}$ \\
\hline Country-year fixed effects & Yes & Yes & Yes & No & No & No \\
\hline Product fixed effects & Yes & Yes & Yes & No & No & No \\
\hline Country fixed effects & No & No & No & Yes & Yes & Yes \\
\hline Agricultural products & Excluded & Excluded & Excluded & Excluded & Excluded & Excluded \\
\hline Observations & 121963 & 121963 & 121963 & 94658 & 94658 & 94658 \\
\hline Adjusted R-squared & 0.01 & 0.01 & 0.01 & 0.0002 & 0.0002 & 0.0002 \\
\hline
\end{tabular}

All regressions include a constant. Robust standard errors are listed in parentheses.

$* * * *$ significant at $10 \%$; ** significant at $5 \%$; *** significant at $1 \%$.

\subsection{Misclassification of imported products}

Finally, we turn to misclassification of products as another potential channel of tariff evasion. We follow Fisman and Wei (2004) and include in our basic specification an additional regressor-the average tariff on similar products which are defined as all other 6-digit products belonging to the same 4-digit HS category. The average is weighted by the share of each product in German exports within each 4-digit HS category. ${ }^{12}$ This additional regressor enters the estimated equation by itself as well as in interaction with the differentiated product dummy. If misclassification takes place, we expect to see a negative coefficient on the tariff on similar products, which would signify that holding the own tariff rate constant, a lower tariff on similar products creates more opportunities for misreporting. If such misclassification is easier for differentiated products, we would expect the coefficient on the interaction term to bear a negative sign.

Table 14: Results with tariffs on similar products.

\begin{tabular}{lllllll}
\hline \multicolumn{1}{l}{ Table 14: Results with tariffs on similar products. } & $(1)$ & $(2)$ & $(3)$ & $(4)$ & $(5)$ & $(6)$ \\
\hline \multirow{2}{*}{ Tariff } & \multicolumn{7}{c}{ Levels } \\
\cline { 2 - 7 } & 0.006 & 0.000 & 0.000 & 0.004 & -0.002 & -0.002 \\
& $(0.001)^{* * *}$ & $(0.002)$ & $(0.002)$ & $(0.004)$ & $(0.006)$ & $(0.006)$ \\
Tariff on similar products & & & & & \\
& 0.003 & 0.001 & 0.002 & -0.001 & -0.001 & 0.001 \\
& $(0.002)$ & $(0.002)$ & $(0.002)$ & $(0.004)$ & $(0.006)$ & $(0.005)$
\end{tabular}

${ }^{12}$ The summary statistics for each importing country are presented in Appendix I Table A3.

Note that using an unweighted average would lead to similar conclusions. 


\begin{tabular}{|c|c|c|c|c|c|c|}
\hline Tariff*Conservative dummy & & $\begin{array}{l}0.013 \\
(0.003)^{* * *}\end{array}$ & & & $\begin{array}{l}0.01 \\
(0.008)\end{array}$ & \\
\hline Tariff on similar products & & 0.002 & & & 0.000 & \\
\hline *Conservative dummy & & $(0.003)$ & & & $(0.008)$ & \\
\hline Tariff*Liberal dummy & & & $\begin{array}{l}0.013 \\
(0.003)^{* * *}\end{array}$ & & & $\begin{array}{l}0.011 \\
(0.008)\end{array}$ \\
\hline Tariff on similar products & & & 0.000 & & & -0.004 \\
\hline *Liberal dummy & & & $(0.003)$ & & & $(0.008)$ \\
\hline Country-year fixed effects & Yes & Yes & Yes & No & No & No \\
\hline Product fixed effects & Yes & Yes & Yes & No & No & No \\
\hline Country fixed effects & No & No & No & Yes & Yes & Yes \\
\hline Agricultural products & Excluded & Excluded & Excluded & Excluded & Excluded & Excluded \\
\hline Observations & 123857 & 123857 & 123857 & 95509 & 95509 & 95509 \\
\hline Adjusted R-squared & 0.6 & 0.6 & 0.6 & 0.00 & 0.0001 & 0.00 \\
\hline
\end{tabular}

Robust standard errors in parentheses. Tariff on similar products is defined as the weighted tariff on all other 6-digit products belonging to the same 4-digit category. Weights are equal to product export shares within the 4-digit category.

* significant at $10 \%$;* significant at $5 \%$; ** significant at $1 \%$.

In contrast to the findings of Fisman and Wei, we do not find that misclassification (at least within the same 4-digit HS category) is prevalent in transition countries. As can be seen in Table 14, tariff on similar products does not appear to be statistically significant in any specification. Neither does its interaction with the differentiated product dummy. Our basic result, suggesting that elasticity of missing trade is larger for differentiated products, remains unchanged in the specification in levels. The overall responsiveness of missing trade to the tariff rate, however, retains its significance in only one specification. These changes in results are most likely due to a high correlation between own tariff rate and the tariff rate on similar products (0.86).

The lack of evidence on misclassification may be attributed to high correlation between own tariff and tariff on similar products or to the possibility that misclassification takes place outside the same 4digit category. For example, when in 2000 Johnson \& Johnson was importing to Russia their "2-in-1 Shower Gel" the company categorized it as a soap substitute, but customs decided to consider the product as a cosmetic and the company had to pay a $20 \%$ instead of a $15 \%$ duty (Aris, 2000). While soap is included in the 3401 HS category (HS 340120 is "soap in other forms"), cosmetics belong to HS 3304 ("beauty, make-up, skin-care, nes").

In sum, our analysis suggests that differentiated products may lend themselves more easily to tariff evasion and that such evasion is likely to take place through misrepresentation of product prices rather than undercounting of physical quantities or misclassifying products. 


\section{Conclusions}

An emerging literature building on Rauch's (1999) paper has demonstrated some unique characteristics of trade in differentiated products. This paper contributes to the literature on differentiated products by postulating that such products may be subject to greater tariff evasion due to the difficulties associated with assessing the quality and thus the price of such products, which creates greater scope for tariff evasion on the part of importers and corrupt customs officials.

Using product-level data on German exports to 10 Eastern European countries we demonstrate empirical support for this hypothesis. We show that the trade gap, defined as the positive discrepancy between the value of exports reported by Germany and the value of imports from Germany reported by an Eastern European importer, is positively correlated with the level of tariff in 8 out of 10 countries, thus generalizing the result of Fisman and Wei (2004) found for China. Further, we demonstrate that the responsiveness of the trade gap to the tariff level is greater for differentiated products than for homogeneous goods. A one-percentage-point increase in the tariff rate is associated with a $0.6 \%$ increase in trade gap in the case of homogeneous products and a $2.1 \%$ increase in the case of differentiated products. Finally, our results indicate that the greater tariff evasion observed for differentiated products tends to take place through misrepresentation of the import price.

While our study does not explicitly focus on the effects of customs reform, its findings suggest that limiting discretion of customs officials, introducing systems allowing for verification of import documents or price comparisons with similar products and introducing effective audits of customs officials are likely to lower tariff evasion. Our results also provide evidence in favor of having a uniform tariff structure which would dampen the incentives and the ability to misclassify imported products.

\section{References}

Anderson, James E. and J. Peter Neary. 2006. "Welfare versus Market Access: The Implications of Tariff Structure for Tariff Reform," Journal of International Economics, forthcoming.

Aris, Ben, 2000. "Russia: Come clean,” Business Russia, Economist Intelligence Unit, October.

Baumgartner, Edward, 2001. "Russia: More harm than goods," Business Eastern Europe, Economist Intelligence Unit, June 4.

Besedes, Tibor and Prusa, Thomas J., 2006. "Product Differentiation and Duration of US Import Trade," Journal of International Economics, forthcoming.

Bhagwati, Jagdish, 1964. "On the Under-Invoicing of Imports," Bulletin of the Oxford University Institute of Statistics, Vol. 2: 389-397. 
Clotfelter, Charles T., 1983, "Tax Evasion and Tax Rates: An Analysis of Individual Returns," Review of Economics and Statistics, Vol. 65 (3) (August): 363-73.

Evans, Carolyn L., 2003. "The Economic Significance of National Border Effects," American Economic Review, Vol. 93 (September): 1291-1312.

Feenstra, Robert, Markusen, James R. and Rose, Andrew K., 2001. "Using the Gravity Equation to Differentiate Among alternative Theories of Trade," Canadian Journal of Economics, Vol. 34 (May): 430-447.

Feinstein, Martin, 1991. "An Econometric Analysis of Income Tax Evasion and its Detection," RAND Journal of Economics, Vol. 62(1) (Spring): 14-35.

Fink, Carsten, Mattoo, Aaditya and Neagu, Cristina, 2005. "Assessing the Impact of Communication Costs on International Trade," Journal of International Economics, Vol. 67(2) (December): 428-445.

Fisman, Raymond and Wei, Shang-Jin, 2004. "Tax Rates and Tax Evasion: Evidence from "Missing Imports" in China," Journal of Political Economy, Vol. 112(2) (April): 471-500.

Little, Ian, Scitovsky, Tibor and Scott, Maurice, 1970. Industry and Trade in Some Developing Countries. A Comparative Study. Published by Oxford University Press for the OECD.

Panagariya, Arvind and Dani Rodrik. 1993. "Political-Economy Arguments for a Uniform Tariff," International Economic Review, Vol. 34(3): 685-703.

Polish News Bulletin, 2000. "Ineffective Customs Control Threatens Domestic Producers, Says NIK Report," September 19.

Pritchett, Lant and Sethi, Geeta, 1994. "Tariff Rates, Tariff Revenue, and Tariff Reform: Some New Facts," World Bank Economic Review. Vol. 8, No. 1 (January): 1-16.

Rauch, James E., 1999. "Networks Versus Markets in International Trade," Journal of International Economics, Vol. 48 (June): 7-35.

Rauch, James E and Casella, Alessandra, 2003. "Overcoming Informational Barriers to International Resource allocation: Prices and Ties," Economic Journal. Vol. 113 (January): 2142.

Shleifer, Andrei and Vishny, Robert W., 1993. "Corruption," Quarterly Journal of Economics. Vol. 110 (August): 681-712.

Slemrod, Joel and Yitzhaki, Shlomo, 2000. "Tax Avoidance, Evasion, and Administration," NBER Working Papers 7473, National Bureau of Economic Research, Inc. 
Tarr, David. 2002. "Arguments for and against Uniform Tariffs" in Development, Trade and the WTO, Bernard Hoekman, Aaditya Mattoo and Philip English, eds. The World Bank:

Washington, DC. 


\section{Appendix I}

The data coverage for individual countries is as follows:

Bulgaria: 2001-2002; Czech Republic: 1996-2001; Hungary: 1992-2001; Latvia: 1996-2003; Lithuania: 1995-2000; Poland: 1994-2003; Romania: 1999-2003; Slovenia: 1999-2003; Russian Federation: 19962003; Ukraine: 1996-2002.

Tariff data are not available for all years. In case of missing data we keep the tax rate constant until a new tariff rate is available. We fill in the tax rates for a maximum of three periods.

In the WITS database, Hungarian imports are reported only if the value is above US\$1000. In order to keep a similar structure, we drop all the exports from Germany whose value is below this threshold. A similar problem arises for Poland. No imports below US\$50,000 are reported by Poland. We apply the same strategy as before by dropping all the exports from Germany whose value is below this cutoff. 
Table A1: Average tariff rate in the first and last year

\begin{tabular}{|c|c|c|c|}
\hline \multirow[t]{2}{*}{ Country } & \multicolumn{3}{|c|}{ Tariff rates } \\
\hline & First year & Last year & Difference \\
\hline & (1) & (2) & $(2)-(1)$ \\
\hline \multirow[t]{2}{*}{ Bulgaria } & 3.91 & 4.01 & 0.10 \\
\hline & (1706 products) & (1747 products) & \\
\hline \multirow[t]{2}{*}{ Czech Republic } & 6.25 & 2.09 & -4.15 \\
\hline & (2785 products) & (2612 products) & \\
\hline \multirow[t]{2}{*}{ Hungary } & 12.94 & 5.55 & -7.39 \\
\hline & (2282 products) & (2193 products) & \\
\hline \multirow[t]{2}{*}{ Latvia } & 3.98 & 3.43 & -0.54 \\
\hline & (1433 products) & (1753 products) & \\
\hline \multirow[t]{2}{*}{ Lithuania } & 3.92 & 3.54 & -0.38 \\
\hline & (1537 products) & (1775 products) & \\
\hline \multirow[t]{2}{*}{ Poland } & 11.78 & 1.90 & -9.88 \\
\hline & (1784 products) & (1756 products) & \\
\hline \multirow[t]{2}{*}{ Romania } & 8.37 & 6.49 & -1.88 \\
\hline & (1929 products) & (2013 products) & \\
\hline \multirow[t]{2}{*}{ Russian Federation } & 12.08 & 10.35 & -1.73 \\
\hline & (2073 products) & (1791 products) & \\
\hline \multirow[t]{2}{*}{ Slovenia } & 10.69 & 0.74 & -9.95 \\
\hline & (2188 products) & (2061 products) & \\
\hline \multirow[t]{2}{*}{ Ukraine } & 7.86 & 7.81 & -0.05 \\
\hline & (1756 products) & (1616 products) & \\
\hline
\end{tabular}


Table A2: Average share of imports from Germany on total imports

Avg. share of imports from Germany on total imports

\begin{tabular}{lc}
\hline & \\
Bulgaria & $15 \%$ \\
Czech Republic & $31 \%$ \\
Huingary & $25 \%$ \\
Latvia & $16 \%$ \\
Lithuania & $17 \%$ \\
Poland & $25 \%$ \\
Romania & $15 \%$ \\
Russian Federation & $12 \%$ \\
Slovenia & $19 \%$ \\
Ukraine & $8 \%$ \\
\hline
\end{tabular}

Table A3: Summary statistics for tariff on similar products

\begin{tabular}{lrrrrr}
\hline Country & Mean & $\begin{array}{c}\text { Standard } \\
\text { deviation }\end{array}$ & Minimum & Maximum & Obs. \\
\hline Bulgaria & 3.31 & 6.19 & 0 & 67 & 3453 \\
Czech Republic & 3.98 & 5.99 & 0 & 138 & 15956 \\
Hungary & 7.78 & 10.72 & 0 & 150 & 21810 \\
Latvia & 4.25 & 6.86 & 0 & 75 & 11754 \\
Lithuania & 3.42 & 6.99 & 0 & 70 & 9927 \\
Poland & 4.46 & 12.50 & 0 & 295 & 17130 \\
Romania & 6.33 & 8.44 & 0 & 98 & 9694 \\
Russian Federation & 11.52 & 8.18 & 0 & 100 & 16243 \\
Slovenia & 6.23 & 7.02 & 0 & 45 & 10367 \\
Ukraine & 8.06 & 8.85 & 0 & 50 & 11682 \\
\hline
\end{tabular}




\section{Appendix II}

Figure A1. Prevalence of corruption in customs vs. responsiveness of trade gap to tariff level

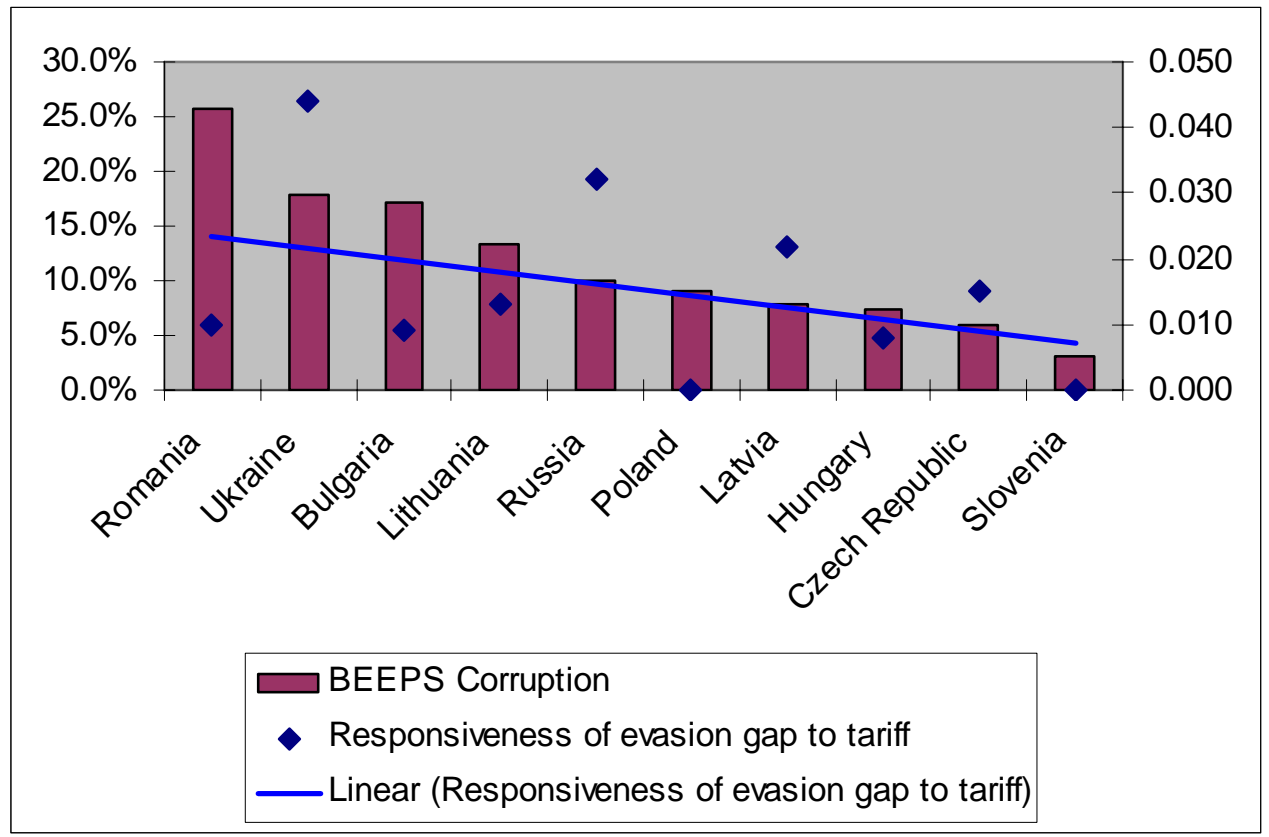

Notes: Responsiveness of trade gap to tariff is equal to the coefficient estimated in Table 4. Statistically insignificant coefficients are set to zero. BEEPS corruption is defined as the percentage of firms reporting that "additional payments" are made "always," "usually" or "frequently" when dealing with customs and imports. It is the average value for the 1999 and 2002 wave of the survey.

The exact questions used in the survey were as follows:

"How frequently do firms in your line of business have to pay some irregular "additional payments" to deal with customs and imports?" (1999 survey)

"Thinking now of unofficial payments/gifts that a firm like yours would make in a given year, could you please tell me how often would they make payments/gifts to deal with customs and import" (2002 survey)

The possible answers were: always, usually, frequently, sometimes, seldom, never. 